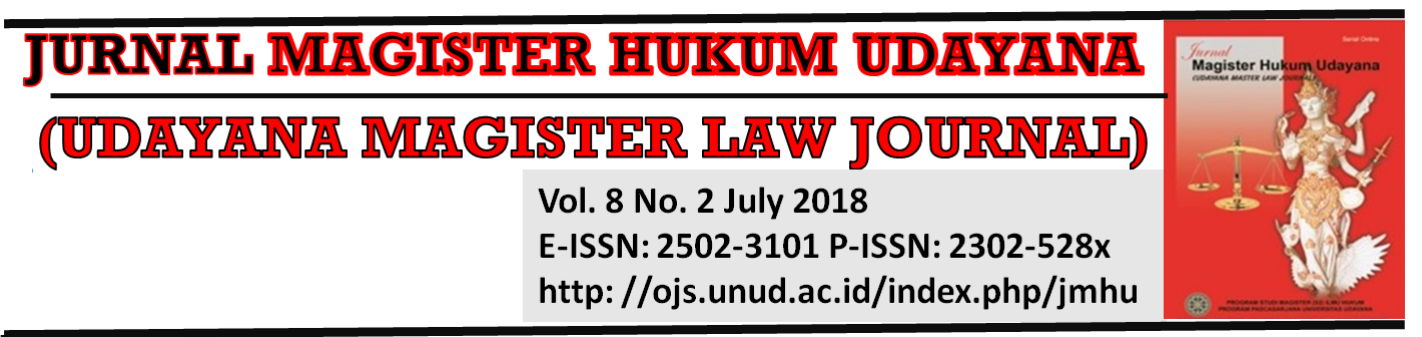

\title{
Do The Foreign Workers Need To Speak Indonesian?
}

\author{
I Made Udiana ${ }^{1}$, I Made Sarjana ${ }^{2}$
}

\author{
${ }^{1}$ Faculty of Law, Udayana University, E-mail: udianabali@gmail.com \\ ${ }^{2}$ Faculty of Law, Udayana University, E-mail: made_sarjana@yahoo.co.id
}

\begin{tabular}{l}
\hline Info Artikel \\
\hline Masuk: $16^{\text {th }}$ June 2019 \\
Diterima: $26^{\text {th }}$ July 2019 \\
Terbit: $31^{\text {st }}$ July 2019 \\
Keywords: \\
Foreign Workers; New \\
Regulation; Speak Indonesia \\
Corresponding Author: \\
I Made Udiana, E-mail: \\
udianabali@gmail.com \\
DOI: \\
10.24843/IMHU.2019.v08.i02. \\
p02
\end{tabular}

\begin{abstract}
The foreign workers are one of the important asset supporting business activities in the globalization era. However, an easy requirement for a foreign worker who works in Indonesia such as dropping language requirement tends to decrease local worker opportunity. The aim of this study to elaborate on the impact of cutting language requirement for foreign workers in new Indonesian regulation. This study uses a comparative approach. The study indicates that Article 36 of the Minister of Manpower Regulation Number 16 of 2015 is contrary to the higher legal norm, namely Article 33 of Law Number 24 of 2009. Based on Stufenbau Theory concerning the Act No. 12 of 2011 concerning the Establishment of Law and Regulation, the lower level will be not applicable. Therefore, revision for the Decree of Manpower Regulation is needed to legal certainty and fairly opportunity for local workers.
\end{abstract}

\section{Introduction}

All citizens residing in Indonesia including foreign workers have the right to work and to be applied fairly, and constitutionally the state should be responsible for the balance of rights obtained both the employment rights of Indonesian workers and foreign workers. This is a guarantee for the creation of legal certainty and justice for all parties. In regulation in Indonesia, it is regulated related to the foreign workforce which must include a professional workforce.

Indonesian history notes that Indonesia has always needed foreign workers to accelerate development in Indonesia. There are several objectives related to the use of foreign workers in Indonesia, as follows: a. Indonesia needs professionals in certain sectors, b. technology transfer will accelerate the transfer of industrial technology. c. increasing foreign investment into Indonesia, $d$. increase employment opportunities for Indonesian workers.

The main capital of the implementation of development is labor, with the aim of people's welfare including labor. ${ }^{1}$ The existence of foreign workers working in the territory of Indonesia must meet the requirements set out in Article 26 of the Minister of Manpower and Transmigration Regulation No. 12 of 2003, (hereinafter referred to as the Regulation of the Minister of Manpower and Transmigration) namely:

1 Udiana, I. M. (2015). Kedudukan dan Kewenangan Pengadilan Hubungan Industria l(The Position and Authority of the Industrial Relations Court), Denpasar: Udayana University Press, p. 15 
1. Foreign Workers employed by employers must meet the following requirements:

a. Possess an educational background that fulfills the requirements of occupation to be occupied by Foreign Workers.

b. Have competencies that are proven by a certificate of competence or work experience in accordance with the position that will be occupied by a Foreign Worker for at least 5 (five) years.

c. Willing to make a statement to transfer their expertise to assisting Indonesian workers, and,

d. Able to communicate in Indonesian.

2. The provisions referred to in paragraph (1) are exempted from the positions of Commissioners, Directors, Impresario service businesses and temporary work.

3. Indonesian Co-Workers as referred to in Clause (1) Letter " $c$ " shall have a background in the field of expertise that meets the position to be occupied by Foreign Workers.

To improve national development, the workforce used in a company is foreign workforces who are experts in their fields. Along with the development of the era of globalization, the workforce is also increasing which is realized by the cooperation between countries in ASEAN through the ASEAN Framework Agreement on Services (AFAS) as outlined in the Presidential Decree Number 88 of 1995 concerning Ratification of ASEAN Framework Agreement on Services. Legal development is carried out through legal reform while still taking into account the diversity of the prevailing legal order and the influence of globalization. This condition is an effort to increase certainty, awareness, service and law enforcement ${ }^{2}$.

The obligation to speak Indonesian is also determined by Law Number 24 of 2009 concerning Flags, Languages and State Symbols (hereinafter referred to as Law Number 24 of 2009). In Article 33 of Law Number 24 of 2009 is set forth:

1) Indonesian language must be used in official communication in government and private work environments.

2) Employees in the work environment of Government and Private institutions as referred to in paragraph (1) who have not been able to speak Indonesian must follow or be included in learning to gain Indonesian language skills.

Mennakentrans Regulation No. 12 of 2003 which regulates foreign workers having the ability to speak Indonesian has been replaced by the Minister of Manpower Regulation No. 16 of 2015 which states that foreign workers are no longer required to have Indonesian language skills. However, in practice the use of foreign workers in Indonesia causes problems that often violate the rules of labor law, the absence of work permits for foreign workers (IMTKA) or they work not in accordance with their expertise and unable to communicate in Indonesian.

The government then revised Minister of Manpower and Transmigration Regulation Number 12 of 2003 with Minister of Manpower Decree No. 16 of 2015 which states that foreign workers are no longer required to have Indonesian language skills. Minister of Manpower Regulation No. 16 of 2015 is contrary to Law Number 24 of 2009, especially

${ }^{2}$ Wantu, F. (2012). Mewujudkan Kepastian Hukum, Keadilan dan Kemanfaatandalam Putusan Hakim di Peradilan Perdata. Jurnal Dinamika Hukum, 12(3). p. 485 
Article 33 which requires using Indonesian language in communicating officially in government and private circles. The formulations of the problems are as follows:

1. Abolition of the rules for using Indonesian language for foreign workers working in Indonesia.

2. Legal efforts to abolish the obligation to use Indonesian language for foreign workers working in Indonesia.

The purpose of this study can be formulated as follows: first, to find out the philosophical foundation of the abolition of the obligation foreign workers to communicate in the Indonesian language, especially the impact that arises for Indonesian citizen workers. Second, legal remedies used to overcome the abolition of the obligation to speak Indonesian for foreign workers.

\section{Research Methods}

This research is categorized as doctrinal research typology or normative legal research in the form of an inventory of positive law and the discovery of legal principles. The approach used in this study is a statute approach to explore and examine aspects of labor law, a conceptual approach to building concepts in labor law derived from views and doctrines, as well as non-legal material. ${ }^{3}$

\section{Results and Discussion}

The definition of foreign workers is every person, not an Indonesian citizen who can do work, both inside and outside the employment relationship to produce goods or services to meet the needs of the community. Further review, the definition of foreign workers can be seen from all dimensions, one of which is determining the contribution to the region in the form of retribution and legal forms of approval of the imposition of retribution. ${ }^{4}$ The presence of foreign workers is a challenge to make employment opportunities increasingly competitive and there is competition for local workers with foreign workers in Indonesia.

After the implementation of the Asian Economic Community, also known as a free market has resulted in the unstoppable presence of foreign workers in and working in Indonesia. Labor competition is getting tougher, resulting in competition for labor. Competition is getting tougher again when the terms of the Indonesian language are abolished for foreign workers, which make it easier for foreign workers to compete with local workers. Indonesia is targeted by foreign workers, all levels of employment including middle to lower jobs are invaded without rules that provide opportunity protection. science and technology transfer work for the people of Indonesia. ${ }^{5}$

The legal basis for the use of foreign workers in Indonesia, first, Law Number 3 of 1958 concerning the placement of foreign workers in Indonesia which subsequently

3 Sunggono, B. (2003). Metode Penelitian Hukum (Legal Research Methods). Jakarta: PT Raja Grafindo Persada.

${ }^{4}$ Khakim, A. (2009). Dasar Dasar Hukum Ketenagakerjaan Indonesia (Principles of Indonesian Labor Law), Bandung: Citra Aditya Bakti.

${ }^{5}$ Diono, M. (2016). Analisis Terhadap Perubahan Ketentuan Penggunaan Tenaga Kerja Asing Melalui Teori Maslahah Mursalah.Jurisdictie, 7(1), p. 35 
underwent a change with Law Number 13 of 2003 concerning Manpower. Law Number 24 of 2009 which regulates the Indonesian Language, consists of several sections and articles, one of which is Article 33, the second section is about the use of Indonesian Language, and Article 44 of the third section about the development, guidance, and protection of Indonesian Language. In this article, it is very clear that every private worker or government must use Indonesian in their work environment. However, with the issuance of Minister of Manpower Regulation No. 16 of 2015 concerning the procedures for the use of Foreign Workers (TKA), the abolition of compulsory Indonesian language for foreign workers. The abolition was intended to facilitate foreign investors entering Indonesia. On the other hand, the abolition of this requirement is contrary to Law Number 24 the Year 2009 Chapter III Article 33 concerning the Indonesian Language.

One of the negative impacts that arise is the presence of foreign workers from various countries with different cultural and linguistic backgrounds, so it will build a thick wall that blocks communication between the Indonesian labor force and the foreign workers who come. ${ }^{6}$ Indonesia should be very grateful and proud of the language it has because not a few nations have conditions that have a language that unites millions of people. This is also accompanied by waning the pride of the Indonesian people with their national language. This situation has brought changes in lifestyle and people's behavior in acting and speaking. The spirit of togetherness has been shifted by individualism, social interaction in public places has lost space. ${ }^{7}$. Many industrial products use English because they provide better status. Coupled with policies that eliminate the mastery of Indonesian language for foreign workers.

Article 36 of the 1945 Constitution of the Republic of Indonesia has implied Language is the identity of a nation. Article 36 is the basis for the making of Law Number 24 of 2009 concerning Flags, Languages and State Emblems and National Anthems. One important area in the development process is cultural development, which is closely related to one of the elements of culture, namely language. Culture is a complex whole which contains the knowledge of belief, art, customs, habits, and also includes language.

Chairperson of the Center for Economic Studies and Community Social Studies at the National Seminar at ISI, Yogyakarta, stated "the government must understand that the mandate of Article 33 of Act Number 24 of 2009 must be adhered to. So, if there are foreign workers who do not speak Indonesian, whatever the proficiency level, they have to leave Indonesia ". On the other hand, there is a need for legal considerations in treating The Minister of Manpower Regulation No. 16 of 2015. In the Unabridged Indonesian Dictionary, consideration is an opinion on good and bad. ${ }^{8}$ Whereas the law is a law to regulate the community so that legal considerations can be interpreted as an opinion of an official decision-maker based on laws and regulations concerning the impact of good and bad policies. Legal considerations are closely related to legal

\footnotetext{
${ }^{6}$ Aziz, A. L. (2014). Penguatan Identitas Bahasa Indonesia sebagai Lambang Identitas Nasional dan Bahasa Persatuan Jelang Penerapan Masyarakat Ekonomi ASEAN (MEA) 2015. Jurnal Studi Sosial, 6(1). p.15

7 Sugono, D. (2015). Peran Bahasa Indonesia Sebagai Alat Pemersatu Dalam Negara Kesatuan Republik Indonesia. Prosiding Seminar Nasional Bulan Bahasa 2015. Unit Penerbitan FKIP Universitas Bengkulu, p. 1-14.

${ }^{8}$ Tim Redaksi. (2005). Kamus Besar Bahasa Indonesia, Jakarta: Balai Pustaka.
} 
reasoning. An official must perform legal reasoning to produce good legal considerations.

Legal reasoning is an activity of problematic thinking from (human) legal subjects as individual and social beings in their cultural circle. Legal reasoning does not seek a settlement to open spaces indefinitely, there are demands for legal reasoning to ensure the stability and predictability of decisions that refer to the positive legal system. Policymakers are not a mouthpiece of the law but must also be fair and beneficial to the wider community. That is, fairness which essentially places something on its portion and gives to anyone following their rights, by the principle that all people are equal before the law (equality before the law). ${ }^{9}$

Bernard Arief Sidartha argues that the activity of thinking of a policymaker is divided into two, namely axiomatic and problematic thinking. Axiomatic thinking begins with unquestioned truth so it is easy enough to draw binding conclusions. Axiomatic thinking is needed to find the basis and justification for an opinion by paying attention to the interrelationship between one legal provision and the other legal provisions. While problematic thinking is the most acceptable legal reason ${ }^{10}$ which considers the stability and predictability of decisions that refer to positive law.

The enactment of Minister of Manpower Regulation No. 16 of 2015 concerning procedures for the use of foreign workers is contrary to Law Number 24 of 2009 Chapter III Article 44; it identifies a conflict of norms. The Law contains the idea of making Indonesian as an International Language. However, with the enactment of Minister of Manpower Regulation No. 16 of 2015, it is obvious that the Indonesian language reaches its goal as an international language. Also, the application of this regulation has reduced the improvement of the function of the Indonesian language. On the other hand, the abolition of Indonesian Language requirements for foreign workers (TKA) has an impact on Indonesian workers who will find it increasingly difficult to find work in the country, especially for those of non-professional workers.

The government should be consistent in carrying out its role to achieve the objectives of Law No. 24 of 2009 Article 44 which makes Indonesian Language as an international language, the public must continue to use, preserve and love Indonesian Language, in accordance with the ideals of the youth pledge announced on October 28, 1928, known as "Youth Pledge". If the Indonesian workforce and foreign workers with good Indonesian language skills are good and right, in the future it will make the Indonesian people face the MEA more confidently and firmly, and actively influence the culture of other nations that will enter Indonesia, rather than being affected and becoming talkative with him. ${ }^{11}$

9 Wantu, F. (2012). Mewujudkan Kepastian Hukum, Keadilan dan Kemanfaatan dalam Putusan Hakim di Peradilan Perdata. Jurnal Dinamika Hukum, 12(3), p. 485

${ }^{10}$ Bernard, A. S, 2009, Refleksi Tentang Struktur Ilmu Hukum, Sebuah Penelitian Tentang Fondasi Kefilsafatan dan sifat keilmuan ilmu hukum dalam konteks keIndonesiaan (Reflection on the Structure of Law, A Study of Philosophical Foundation and the nature of scientific knowledge of law in the context of Indonesia). Bandung: MandarMaju.

${ }^{11}$ Aziz, A. L. (2014). Penguatan Identitas Bahasa Indonesia sebagai Lambang Identitas Nasional dan Bahasa Persatuan Jelang Penerapan Masyarakat Ekonomi ASEAN (MEA) 2015. Jurnal Studi Sosial, 6(1). p.14 
The meaning of the content of the text of Youth Oath is one of the important milestones in the course of the Indonesian nation. The pledge and promises of the young and Indonesian people in the second youth congress made one of the initial grounds for championing Indonesia as an independent and sovereign nation. This is the original sentence of the Youth Pledge of October 28, 1928. The second youth congress was held for two days on October 27 and 28, 1928 in Batavia or Jakarta, on the second day of the congressional youths to state that "homeland and their "language" is one.

Keep in mind what Bung Karno said "Give me 1000 old people, I will undoubtedly remove Mount Semeru from its roots. Give me 10 young men I will surely shake the world. (Don't ask what the State gave us, but ask what we can give to the State).

Liliana Muliastuti, the chairman of teaching affiliates and activists of BIPA, the Indonesian Language for Foreign Speakers (APPBPA) 2015-2019, regretted the abolition of the regulation on the requirement for foreign workers to be able to speak Indonesian. She said that the Law is strategic to protect Indonesian human resources and Indonesian language. Also, the results of the ILO (International Labor Organization) research that immigrant workers who master the local language will perform better than those who do not.

Foreigners who come to Dyan feel they need to be taught Indonesian to facilitate communication with coworkers in everyday life such as when they order food in a restaurant, order a taxi, go to airport, shop, go on vacation, etc.

It is different as Laode said as the Ombudsman Commissioner, a large number of foreign workers entered Indonesia due to changes in the Minister of Manpower Regulation No. 16 of 2015 has resulted in the most fundamental problem that caused the invasion of foreign workers to Indonesia. Bhima Yudhistira Adinegara said Indonesian language skills must remain a mandatory requirement for foreign workers in Indonesia.

As a tool for communication, Indonesian plays an important role in the process of transferring knowledge and abilities, meaning that the basic ability of Indonesian language must be mastered by foreign workers so that it is not the way it is today causing problems of communication with local workers in a company.

\section{Conclusions}

The results of this study indicate that there is a conflict of norms between the Minister of Manpower Regulation Article 33 of 2015 concerning Foreign Workers who are no longer required to have the ability to speak Indonesian, with Article 36 of Law No.24 of 2009 concerning Flags, Languages and State Emblems.

\section{Bibliography}

\section{$\underline{\text { Books }}$}

Budiono, A. R. (1995). Hukum perburuhan di Indonesia. Jakarta: RajaGrafindo Persada.

Khakim, A. (2009). Dasar Dasar Hukum Ketenagakerjaan Indonesia. Bandung: Citra Aditya Bakti.

Sunggono, B. (2003). Metode Penelitian Hukum (Legal Research Methods). Jakarta: PT Raja Grafindo Persada. 
Udiana, I. M. (2015). Kedudukan dan Kewenangan Pengadilan Hubungan Industrial, Denpasar: Udayana University Press.

Sidharta, B. A. (2009). Refleksi tentang struktur ilmu hukum: sebuah penelitian tentang fundasi kefilsafatan dan sifat keilmuan ilmu. Bandung: Mandar Maju.

\section{Journal}

Aziz, A. L. (2014). Penguatan Identitas Bahasa Indonesia sebagai Lambang Identitas Nasional dan Bahasa Persatuan Jelang Penerapan Masyarakat Ekonomi ASEAN (MEA) 2015. Jurnal Studi Sosial, 6(1). 444-458.

Diono, M. (2016). Analisis Terhadap Perubahan Ketentuan Penggunaan Tenaga Kerja Asing Melalui Teori Maslahah Mursalah.Jurisdictie, 7(1), 3343. http://dx.doi.org/10.18860/j.v7i1.3677

Prasetyo, B. (2014). Menilik Kesiapan Dunia Ketenagakerjaan Indonesia Menghadapi MEA. Jurnal Rechts Vinding Online, Media Pembinaan Hukum Nasional. 1-7.

Puspitasari, R. V., Harianto, A., \& Ana, I. B. O. (2018). Kepastian Hukum Pengaturan Penggunaan Tenaga Kerja Asing di Indonesia.Lentera Hukum, 5(3), 367-379. https://doi.org/10.19184/ejlh.v5i3.6839

Sugono, D. (2015). Peran Bahasa Indonesia Sebagai Alat Pemersatu Dalam Negara Kesatuan Republik Indonesia. Prosiding Seminar Nasional Bulan Bahasa 2015. Unit Penerbitan FKIP Universitas Bengkulu, 1-14.

Wantu, F. (2012). Mewujudkan Kepastian Hukum, Keadilan dan Kemanfaatan dalam Putusan Hakim di Peradilan Perdata. Jurnal Dinamika Hukum, 12(3), 479-489. http://dx.doi.org/10.20884/1.jdh.2012.12.3.121

\section{Laws and Regulations}

The 1945 Constitution of the Republic of Indonesia

Law Number 13 of 2003 concerning Labor

Minister of Manpower and Transmigration Regulation Number 12 of 2003 concerning Requirements for Foreign Workers to Work in Indonesian Territory

Law Number 24 of 2009 concerning Flags, Languages and State Symbols

Minister of Manpower Regulation Number 16 of 2015 concerning the Abolition of

Obligations for Foreign Workers of Using Indonesian Language. 